\title{
Todos ali eram bons homens
}

\author{
Everyone there was good men
}

\section{Leonardo Josef Schifino Wittmann}

Não há mais cogumelos nem cerejas por aqui, meu amigo. Você chegou um ano atrasado, o velho completou, assim como se falasse do preço dos pãezinhos. Mas eu insisti, dizendo que procurava alguém importante para mim, alguém que trabalhava naquele lugar sobre o qual ninguém mais quer falar. $\mathrm{O}$ velho se demorou a me dar resposta, mas enfim perguntou se eu tinha certeza de que ela ainda estava viva. Eu disse que tinha sim alguma certeza, mas ele disse que alguma certeza e nada eram quase equivalentes. Ele baixou a meia e coçou a perna. Pediu que contasse mais sobre essa pessoa pois, assim sem informação nenhuma ou de qualquer jeito, não tem como achar ninguém.

Conheci Daryna longe dali, num país melhor e sem esses perigos todos, moramos três meses juntos até que ela voltou para cá. E por acaso não sabe o sobrenome dela, ele perguntou, e eu o disse. O velho ficou a pensar e eu me virei para enxergar melhor, lá ao longe, a roda gigante ignorada. Daryna disse que aquela tinha sido a única que sua mãe vira em toda a vida, e agora eu a via pela primeira vez.

Ela trabalhava na usina junto com o pai e morava em Pripyat, sim, o velho falou alto para ganhar minha atenção. Mas agora só há vultos esquecidos naquela cidade, meu jovem. Com isso imaginei Daryna caminhando lá sozinha, por vezes se divertindo na roda gigante enferrujada. Não sei que fim ela levou, ele disse, assim como se falasse do aumento do preço de um maço de cigarros.

Eu perguntei onde conseguiria mais informações e o velho deu de ombros. Pois eu não sei, meu amigo, passo o dia sentado, sem saber bem o que fazer, só pensando que aqui todos eram bons homens, bons homens que agora levarão um peso que não lhes cabe. Isso ele já falou como se falasse que acordou sem três dentes e sangrando, depois apontou para o reator destroçado, ainda mais longe do que a roda gigante, e xingou-o de maldito, de peste, de algo que enfim só traz azar e tristeza. Ali o velho quase chorou e eu falei, meio sem jeito, que precisava ir embora, que precisava procurar Daryna. Ele baixou a meia e coçou a perna de novo, dizendo que ainda havia cadáveres dentro daquela usina desgraçada. Me afastei com um adeus tímido, enquanto ouvia sua voz agora miúda resmungar que aquele reator acabou com a nossa terra rosada, que ainda é rosada, mas ninguém mais se importa, nem se a terra ficasse roxa.

Que o senhor não se demore muito por aqui, me disse a jovem dona da pensão enquanto seu filho chutava uma bola para o alto como quem chuta algo muito pesado mas sabendo que é leve. Eu disse que precisava encontrar Daryna. A mulher me encarou sem saber de quem eu falava e me ofereceu o único quarto vago, que era o único quarto da pensão, pois ela assim chamava a sua casa. É claro que o senhor não pensa em ir nem perto de Pripyat, ao que eu respondi que achava que não, pois o velho a alguns metros dali me recomendara o mesmo. A mulher respondeu que o perigo são as ondas invisíveis que Pripyat emana, ondas que transformam as pessoas, que as fazem sumir da nossa vista. Que as obrigam a se isolar da gente, completou o menino. Recomendo que o senhor volte logo para a sua terra, mais segura e bonita do que esta, que hoje é rala e sem nenhuma pegada nova.

Pois à noite sonhei com Daryna presa na usina e decidi ir até lá. A mulher me alertou que não o fizesse, pois traria as ondas invisíveis comigo. Daí o senhor não poderá mais nos visitar, disse o menino, hoje sem a bola. A mãe completou que a nossa infelicidade é só nossa, senhor, não precisamos de um estrangeiro para pegar uma fatia dela e assim achar que nos ajuda. Mas a minha infelicidade não está aqui, eu disse, está lá no lugar de onde venho. A mulher alisou o lado esquerdo do pescoço e disse que ali não havia felicidade possível, pergunte para mim, pergunte aqui para o meu garoto, pergunte para o velho que dia e noite se ocupa apenas em encarar aquele reator, como se o pudesse destruir com a vista. Nós aqui carregamos mais infelicidade do que felicidade, mas não dividimos essa infelicidade com mais ninguém, pois ninguém merece tal pobreza. Eu não soube o que responder e por isso me virei em direção à usina. O menino perguntou e se caso ela não estiver lá, senhor?

$\mathrm{O}$ velho estava errado, pois nem vultos esquecidos haviam ali. Esqueceu-se prédios, ruas, bonecas, carrosséis, a roda gigante. Porque um lugar só tem vultos se um 
dia já teve quem se transformasse neles, e Pripyat me pareceu uma cidade que nunca aceitou esses pré-vultos, uma cidade que já brotara com as suas ferrugens, as suas gramas nunca aparadas e a sua desolação constante. Mas daí lembrei que sim, que alguns ali moraram, alguns dali fugiram e alguns ali tombaram. E assim dei razão ao velho e atravessei a cidade olhando e projetando cada canto como um canto em que Daryna tivesse se escondido, se escorado, aberto um sorriso cúmplice, ou sem jeito, ou tristonho.

Nenhum rastro dela na usina, e disso tirei que ela ainda estava por aí, perambulando ou mesmo fixa em algum lugar, em algum lugar que talvez eu a encontrasse um dia. Sentei e percebi que aquela usina não era uma usina em absoluto: era um prisão, uma prisão para os espectros. E uma prisão também para mim, um espectro ainda em construção, preso no lugar onde pensei que Daryna estivesse presa.
Foi uma burrice o senhor vir aqui. Perguntei o que ele era, e ele disse: se ajuíze e saia daqui o quanto antes. Eu respondi que não podia voltar impregnado de ondas. Ele gritou o senhor ainda tem uma chance, vá, corra, corra por Pripyat, corra para bem longe, corra e leve a mulher e o garoto, que merecem uma vida melhor. O senhor vive num país bom e austero, um país onde aqueles dois talvez tenham um futuro. Não, eu disse, não posso ajudá-los a ter um futuro por lá. Lá sou eu que não tenho um futuro, pois veja que abandonei tudo para encontrar Daryna. Ele disse: maldita seja esta terra, esta terra antes tão bonita e que hoje só traz desolação. Mas a pior desolação, eu disse, é aquela que trazemos dentro de nós, aquela da qual não queremos nos desvencilhar de tão íntima que é, pois o que nos restaria se o fizéssemos?

Recebido: 08/11/16

Aprovado: $15 / 02 / 17$

Contato: leowittmann@gmail.com 